AperTO - Archivio Istituzionale Open Access dell'Università di Torino

\title{
Umlaut extension in German modals as natural change
}

\section{This is the author's manuscript}

Original Citation:

Availability:

This version is available http://hdl.handle.net/2318/127964

since

Terms of use:

Open Access

Anyone can freely access the full text of works made available as "Open Access". Works made available under a Creative Commons license can be used according to the terms and conditions of said license. Use of all other works requires consent of the right holder (author or publisher) if not exempted from copyright protection by the applicable law. 


\title{
Umlaut extension in German modals as natural change ${ }^{*}$
}

\author{
Livio Gaeta
}

Università di Torino

To the memory of Gustav Wurzel

\section{Introduction}

The German Preterit-Presents (= P-Ps) dürfen, können, mögen and müssen display an umlauted vowel in the plural of the present indicative and in the infinitive, which is unexpected from the viewpoint of historical development. Let us first take a look at the complete paradigms of NHG P-Ps:

* Parts of this paper were presented at the Zentrum für Allgemeine Sprachwissenschaft, Berlin, at the Colloque international sur les systèmes des verbes modaux dans les langues romaniques et germaniques, Antwerpen, December 10-12, 1998, and at the IX International Morphology Meeting, Vienna, February 25-27, 2000. I would like to thank the people present on all these occasions for discussing parts of the paper with me. Moreover, the paper has benefited from discussions with D. Bittner, W.U. Dressler, J. Salmons and W.U. Wurzel. I am deeply indebted to B. Joseph and to two anonymous reviewers for their helpful remarks, and to J. Hunt for checking my English. Needless to say, any errors still remaining are mine. The following abbreviations are used in the text: Goth. = Gothic, IF = inflectional feature, Lat. = Latin, $\mathrm{MHG}=$ Middle High German, $\mathrm{NHG}=$ New High German, ODan. = Old Danish, OE $=$ Old English, OHG = Old High German, OIc. = Old Icelandic, ONor. = Old Norwegian, OS $=$ Old Saxon, OSw. $=$ Old Swedish, PGmc. $=$ Proto-Germanic, P-P = preterit-present, $\mathrm{PSC}=$ paradigm structure condition. 
(1)

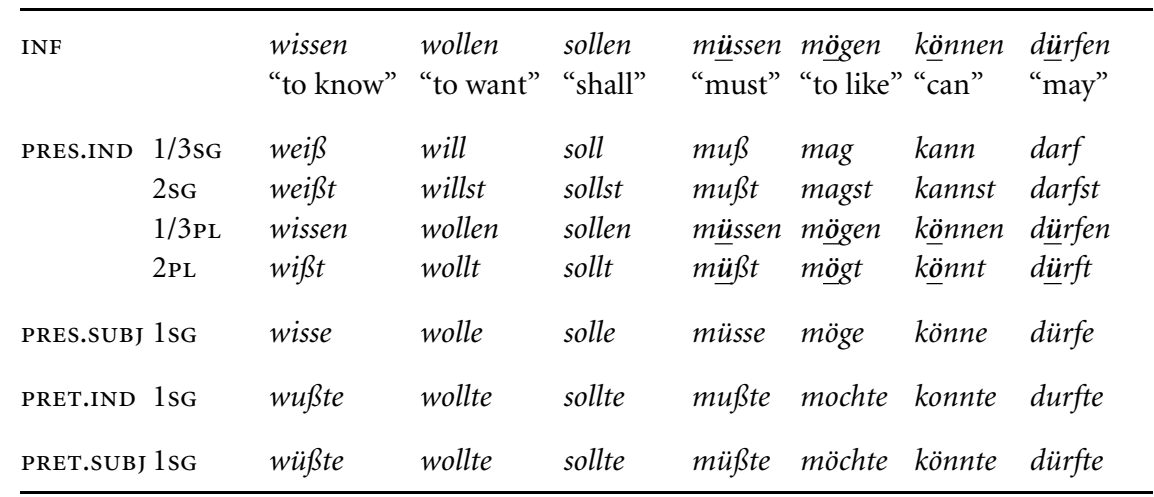

The underlined forms in (1) display umlaut, i.e., the well-known vowel alternation resulting from an assimilation process which affected $\mathrm{OHG}$ vowels when followed by a palatal vowel or glide, e.g., OHG hano/henin "cock (NOM/GEN)". In the OHG forms, the vowel alternation was purely phonologically governed by a rule of vowel harmony, consisting in the raising of the stressed short /a/ to /e/ when followed by /i, j/ except for a number of blocking contexts, cf. Iverson et al. 1994 (so-called primary umlaut). Later, a more extensive process of fronting affected all vowels, whereas the front mid-low vowel, usually noted as /ë/ in the German linguistic tradition, originating from PGmc. /e/ or /i/ was raised to /e/ (e.g., MHG breter "boards" < OHG brëtir, cf. Paul/Wiehl/Grosse 1989: 63, 66), when followed by /i, j/ (so-called nonprimary umlaut, cf. Iverson \& Salmons 1996; 1999 for details). The umlaut rule underwent a process of morphologization as a consequence of the late OHG radical weakening of unstressed vowels, which made the context triggering umlaut opaque. At this point, the initially phonologically governed alternation was completely morphologized (or grammaticalized, cf. Wurzel 1980; 1984; Gaeta 1998), giving rise to the actual alternation shown for instance by the preterit subjunctive forms that display umlauted vowels with respect to the preterit indicative.

The umlaut extension shown by the emphasized vowels in (1) is regularly found in the plural present indicative and in the infinitive of a handful of P-Ps in MHG sources, where however umlautless forms also occur (cf. Paul/Wiehl/Grosse 1989:264): 
(2)

\begin{tabular}{ll}
\hline OHG & MHG \\
\hline 1/3PL.PRES.IND/INF & 1.3PL.PREs.IND = INF \\
tugun/tugan "to help" & tugen, tügen \\
gunnun/gunnan "to grant" & gunnen, günnen \\
kunnun/kunnan "to understand" & kunnen, künnen \\
durfun/durfan "to need" & durfen, dürfen \\
(gi)turrun/turran "to dare" & turren, türren \\
sculun/sculan "to have to" & suln, süln \\
mugun/mugan "to be able to" & mugen, mügen \\
magun/magan & magen, megen \\
muozun/muozan "may" & muozen, müezen \\
\hline
\end{tabular}

For the P-P magan two different forms are found in the sources, cf. magun/ mugun and magan/mugan. However, the forms mugun/mugan are generally assumed to be a later development (cf. Braune/Eggers 1987:302), although it is not completely clear how we should reconstruct the initial PGmc. forms. ${ }^{1}$ In all these cases, it is not possible to explain away the presence of umlaut on the basis of an earlier high segment in the following syllable, since the plural ending and the infinitive ending go back respectively to PGmc. ${ }^{\star}$-um and ${ }^{\star}$-an (e.g., Goth. magum/magan, cf. Ramat 1986:201f.), which did not give rise to umlaut. Therefore, the umlaut occurring in the plural present indicative forms and in the infinitive of the four NHG verbs dürfen, können, mögen, and müssen is unexpected, i.e., it does not have a phonetic origin, and must consequently be explained in other ways.

The paper is organized as follows. Section 2 will discuss the relevant literature on the topic, with the aim of emphasizing the most important conclusions that can be drawn from previous studies. Section 3 will present the picture of P-Ps

1. Cf. Seebold (1970:342): "Die Zugehörigkeit zu einer Ablautreihe ist unsicher, sowohl vom gm. als auch vom etymologischen Standpunkt aus. Die VI. Reihe müßte eigentlich - $\bar{o}$ — im Präterito-Präsens haben (vgl. $m \bar{o} t$ ), während die V. Reihe Wechsel $a / \overline{\mathcal{k}}$ zeigen sollte. Wenn im Präterito-Präsens auch in der V. Reihe der ältere Wechsel $a$ /- bewahrt blieb (vgl. man und skal), wäre im Plural eigentlich $e$ zu erwarten. Eine Schwundstufe idg. ${ }^{\star} m g$ - ist insofern unbeweisbar, als die Formen mit gm. $u$ gegenüber denen mit $-a$ - jüngerer zu sein scheinen. Dennoch wird man wohl von einem derartigen Wechsel mag-/mug- mit analogischem Ausgleich nach dem Singular ausgehen müssen; wobei unklar bleibt, warum die ältere Form mug-zuerst zurückging (und ganz ausstarb?) und dann wieder (neu gebildet?) stark um sich griff". 
in $\mathrm{OHG}$, introducing a few theoretical notions that will open the way for a new interpretation of the facts. The final Section 4 draws the general conclusions.

\section{Umlaut in the P-Ps: Previous approaches to the problem}

In the last century, several attempts were made to explain the unexpected presence of umlaut in the German P-Ps, yet Mettke (1989:205) observes that there is "keine eindeutige Erklärung". Clearly, the amount of literature that has accumulated on the topic cannot simply be disregarded. While maintaining that up to now we do not have any satisfactory explanation, several interesting partial conclusions can be collected from the work of previous scholars which form a clear picture under a theoretically better-founded perspective. This is what I will argue in this section, discussing and rejecting several proposals found in the literature, but rescuing the baby from the bathwater.

\subsection{First attempts to explain the presence of umlaut}

Chronologically, the first attempt to provide an explanation to the problem is found in Weinhold (1883:440), who assumes that the umlaut was extended to the plural present indicative (and hence to the infinitive) from the present subjunctive, where it regularly arose due to the presence of an $i$-suffix (cf. OHG kunni > MHG künne). The employment of subjunctive forms instead of the indicative in the case of modal verbs explains why this over-extension could take place. In a slightly different way, Ščur (1961) has proposed that the process of over-extension from the subjunctive forms first affected the infinitive, which was reshaped on the basis of the 3rd plural present subjunctive to preserve the identity with the 3 rd plural present indicative which arose from the weakening of unstressed syllables. The latter was undermined by the appearance of forms ending with the suffix $-n t \sim-n d$ coming from the other inflectional classes (as in grifent "they grasp", habēnt "they have" vs. wizzun "they know"). From the infinitive it was subsequently extended to the plural present indicative. ${ }^{2}$ The explanations proposed by Weinhold (and Ščur), abstracting from the details distinguishing them, meet with a major problem. As already observed by Behaghel (1928), the marked and less frequent form, i.e. the present subjunctive,

2. For a similar proposal, but with different arguments, cf. more recently Beckmann (1990). 
is supposed to replace the unmarked and more frequent one, i.e. the present indicative: ${ }^{3}$

Der Gedanke, daß der Umlaut aus dem Konjunktiv stamme, ist abzulehnen. Denn eine syntaktische Berührung zwischen dem Indik. und Konj.Präs. findet im selbständigen Satz nicht statt, da der Konj.Präs. hier überhaupt kaum je gebraucht war; es ist vielmehr der Konj.Prät., der sich im selbständigen Satz mit dem Indik.Präs. in der Bedeutung berührt. So würde auch der Sieg des Konjunktivvokals ganz unverständlich sein, denn der Indikativ kam im Hauptwie im Nebensatz vor, war also zweifellos häufiger. (Behaghel 1928:483)

Behaghel preferred another explanation, already proposed by Brenner (1895). According to these scholars, the umlaut regularly arose from a phonological change. Crucial for this explanation is the fact that the OHG umlaut rule took as a domain the phonological word, although recent analyses of umlaut barely mention it (cf., among others, Voyles 1991, and, for a radically different interpretation, Janda 1998). In fact, primary umlaut, and later nonprimary umlaut, were also triggered by / $\mathrm{i}, \mathrm{j} /$ of a following clitic element, which formed a single phonological word with the word bearing the primary stress (cf. Behaghel 1928:292):

(3)

$\begin{array}{ll}\text { meg } i z<\operatorname{mag} i z & \text { "may it" } \\ \text { meg ih }<\text { mag ih } & \text { "may I" } \\ \text { scel iz< scal iz } & \text { "shall it" } \\ \text { leg } i z<\operatorname{lag} i z & \text { "lay it" } \\ \text { drenc ih }<\text { drank ih } & \text { "drank I" } \\ \text { geb ima }<\text { gab imo } & \text { "gave him" } \\ \text { gireh inan }<\text { girah inan } & \text { "avenged them" }\end{array}$

According to Brenner and Behaghel, it was the high frequency of cases in which the plural clitic pronoun was postposed as in durfen wir $\rightarrow d[y]$ rfen wir, kunnen sie $\rightarrow k[y]$ nnen sie, etc., that determined the extension of umlaut to the

3. Behaghel's claim must not be intended as a general statement concerning the universal markedness relations between the indicative and the subjunctive mood. In fact, it is possible under certain conditions (that must be carefully specified) to observe language changes that run against the general trend as shown by the case of the Italian 1st person plural present indicative -iamo (cf. lod-are "to praise" / lod-iamo, tem-ere "to fear" / tem-iamo, etc.), which originally was a subjunctive suffix (< Lat. laud-eāmus, tim-eāmus, etc.), and was then extended to the present indicative of all inflectional classes (cf. Vincent 1980). For these cases, it is useful to speak of markedness reversal (see $\$ 2.2$ below). Instead, Behaghel's claim is related to the observed fact that in OHG, as well as in modern German dialects (cf. Schirmunski 1962:508), the use of the present subjunctive is rather scarce. 
plural present indicative, whence it passed to the infinitive. Consider that a final $-n$ was optionally deleted in the case of a postposed pronoun, and especially wir: OHG wizzuwir, wege wir (cf. Braune/Eggers 1987:260), MHG neme wir, name wir, also with syllable deletion: nem wir (cf. Paul/Wiehl/Grosse 1989:242). ${ }^{4}$ These deletions can be interpreted as a clear-cut signal of cliticization of the postposed pronoun. Notice that similar changes occurred in several Upper German dialects, also in verbs not belonging to the P-Ps class (cf. Behaghel 1928:292):

(4) Alem. chömme

$$
(<\text { cho }+ \text { mer }) \text { "we come" }
$$$$
\text { gömmer }
$$$$
\text { stömmer }
$$

Bavar. gengemer stendemer

This phenomenon is particularly widespread in the Alemannic and Bavarian dialects, especially in highly frequent verbs such as gehen "to go", stehen "to stay", tun "to do", etc. (e.g., Swabian IND.Pres.sg $g a u^{n}(n) / g \bar{o}^{n} n$, šdand/ šdōd, duər, pl. $g e^{n} n d, \check{s} d e^{n} n d, d e e^{n} n d$, cf. Schirmunski 1962:559), where we find an umlaut alternation between the singular and the plural present indicative similar to P-Ps. Moreover, we still find sporadic cases in which the umlaut in external sandhi has been preserved, as in the forms züemer "to me", züenen "to them", züenis "to us" (< zuo mir, zuo inen, zuo üns) documented in Toggenburg (cf. Behaghel 1928:288).

Against this explanation, it has been objected (cf. Fiedler 1928; Ščur 1961; Birkmann 1987:195) that there are only a few cases where syntactic umlaut is indicated in the manuscripts. This is of course true, but it does not necessarily militate against Behaghel's theory. In fact, it is not surprising that an allophonic variation like umlaut might have been reflected irregurarly in writing (cf. for a recent discussion Fertig 1996), especially — as is often the case ${ }^{5}$ — when

4. This phenomenon was very widespread in MHG, and was still very common in early NHG, as reported by Fertig (2000:47).

5. Phonological processes involving domains wider than the prosodic word are usually not shown in writing, presumably because they do not give rise to paradigmatic alternations, given their syntagmatic character. A good example is provided by the well-known phenomenon of Raddoppiamento sintattico ("syntactic doubling", cf. Loporcaro 1997) which occurs in Italian. This arose as a consequence of an assimilation rule concerning morpheme-ending obstruents (cf. It. a [r:]iva "to the shore" < Lat. ad ripam, It. arrivare "to arrive" < Lat. adrīpāre) and is still found both in internal (e.g., cosiddetto "so-called" < Lat. (ec)cu sic 
umlauted forms occurred in contexts wider than a prosodic word. Only at a later stage, when these umlauted forms had slowly been morphologized as signals of this specific conjugational class, do we find a more regular notation of the umlauted vowels. ${ }^{6}$ Then, when umlaut lost its phonetic motivation, those cases where umlauted vowels emerged such as the examples in (3) disappeared completely. Nonetheless, on the basis of the available documentation, we can be sure that the process of umlaut was very widespread, determining a high number of neutralizations in domains wider than the prosodic word. Thus, the umlaut cases pointed out by Behaghel and also found in the modern Bavarian and Alemannic dialects must be considered a fact. However, this fact in itself does not make clear why umlaut occurs only in the plural present indicative and in the infinitive, and not, say, in the singular present indicative, where it is also attested (cf. in (3) meg ih). In other words, it is not clear in Brenner's (1985) and Behaghel's (1928) explanations why umlaut was only preserved in the plural present indicative and the infinitive of P-Ps (cf. Fiedler 1928 for similar objections). ${ }^{7}$

Another objection that can be raised against this theory is related to the distinction between primary and nonprimary umlaut that has been recently renewed by Iverson \& Salmons $(1996 ; 1999) .{ }^{8}$ In fact, Brenner's/Behaghel's explanation does not take into account the qualitative difference existing between primary umlaut present in cases like the ones quoted above in (3), and the possible presence of nonprimary umlaut in a form like $k[y]$ nnen sie. Whereas primary umlaut only raised a stressed /a/ immediately followed by a high segment, nonprimary umlaut fronted back vowels within a phonological word (but cf. the case of /ë/ raising mentioned above). Therefore, the examples mentioned above in (3) cannot be directly connected with the umlaut of, say, megen sie, because in the latter case the umlauted /a/ is not immediately

dictum) and in external sandhi (e.g., così [d:]ice "s/he says so" < Lat. (ec)cu sīc dīcit). However, only the first case is indicated in writing.

6. However, Fertig (2000:56) still observes a huge inconsistency in the marking of umlaut in his corpus of Nuremberg texts of the sixteenth century.

7. Moreover, as observed by Birkmann (1987: 195), this "phonological" explanation does not make clear the case of over-extension of umlaut in the OIc. forms málmegu. In OIc., umlaut could not arise as a consequence of a phonologically conditioned process since OIc. clitic pronouns did not display umlaut-triggering high front vowels (cf. vér, pér, peir, pau, Noreen 1923:309ff.). I will return to this point later.

8. I am grateful to one of the reviewers for pointing out this fact to me. 
followed by the triggering segment. Moreover, as also demonstrated by forms like meg $i z$, primary umlaut was quite regularly indicated in the sources, whereas nonprimary umlaut was essentially more sporadic. This is, however, only partially true. In fact, examples can be quoted where primary umlaut had a wider domain: they are usually mentioned among the changes affecting the middle unstressed vowels as in negili "nails", epfili "apples", etc. (cf. Braune/Eggers 1987:70). These examples clearly show that, at least in late OHG, the palatal harmony affected the whole phonological word. ${ }^{9}$ Moreover, these objections in my opinion concern Brenner's/Behaghel's theory only orthogonally. In fact, what Brenner and Behaghel actually show is that the umlaut extended to the domain of phonological words, which is true both for primary umlaut, as shown above, and for nonprimary umlaut, as demonstrated by MHG forms like sem mir "so to me" < sam mir, tete "did I" < tët (e) ich (cf. Paul/Wiehl/Grosse 1989:67), and by the evidence from Upper German dialects discussed above.

Leaving this phonological terrain for the moment, let us review another very tricky - proposed explanation of the extension of umlaut in plural present indicative of P-Ps. According to Fiedler (1928), umlaut was extended to the plural present indicative of P-Ps on the basis of an analogical matching with the inflectional class of verbs displaying so-called Rückumlaut (cf. Vennemann 1986; Ronneberger-Sibold 1990a). The latter is an instance of rule inversion (cf. Vennemann 1972), in which a generalization of the inverse rule took place on the basis of the occurrence of the sound alternation in a grammatical category considered semantically secondary or marked (cf. Vennemann 1974:139). In the MHG period, as a consequence of the loss of phonetic motivation for the umlaut rule, the following verbal paradigms emerged (cf. Paul/Wiehl/Grosse 1989:256f.):

$\begin{array}{lll}\text { (5) OHG } & \text { INF. senden } & \text { PRET. santa "to send" } \\ \text { MHG } & \text { senden } & \text { sante } \\ \text { OHG } & \text { (ir-)fullen } & \text { (ir-)fulta "to fill" } \\ \text { MHG füllen } & \text { fulte }\end{array}$

9. That the phonological word must be considered a relevant phonological unit in OHG is shown by other changes affecting for instance unstressed vowels that underwent assimilation due to a following clitic: naman thar < namun thar, diufil ir < diufal ir (cf. Braune/Eggers 1987:69). For a reanalysis of the relation between primary and nonprimary umlaut, cf. Howell \& Salmons (1997), and Gaeta (2002) for a thorough discussion of the phonological domain and conditions of umlaut in early and late OHG. 
This alternation concerned verbs of the -jan class (cf. ${ }^{\star}$ sandjan,${ }^{\star}$ fulljan), which displayed, at least historically, particular phonological properties. Here, a rule of syncope deleted the palatal vowel when the latter occurred in a light syllable between a primary-stressed heavy syllable and a secondary-stressed one (cf. Vennemann 1986:706 for details). Interestingly, Rückumlaut was extended analogically in the MHG period to other verbs, as in MHG enden "to end", preterit ante "ended" with respect to the OHG forms entiōn, entiōta, where the same alternation occurs as in senden-sante. Vennemann speaks in this instance of rule inversion. Where the phonological rule of umlaut caused sound alternation within the verbal paradigm, a restructuring that inverted the interpretation of the surface forms took place. The real change is assumed to occur in the preterit form - a grammatical category semantically secondary or marked with respect to the present tense - which now alternates with the present on the basis of the well-attested model senden-sante. Thus, the Rückumlaut has given rise to extensions on the basis of the following four-part analogy:

(6) senden : sante $=$ enden $: \mathrm{X}($ ante $)$

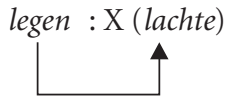

According to Fiedler's explanation, the presence of umlauted forms in the plural present of modals is due to the action of an analogical extension of the Rückumlaut to this verbal class. In his idea, the extension of umlaut to the P-Ps took place on the model of the Rückumlaut following the four-part analogy:

(7) legen: lahte $=\mathrm{X}($ megen $):$ mahte

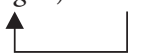

However, this hypothesis is unconvincing in my opinion because the analogical reanalysis must have taken place inversely with respect to its normal behaviour. As we have seen above, the (semantically) secondary forms of the past are usually remade on the basis of the inverted rule, and not vice versa. If we agree with Fiedler's explanation, we are forced to assume that the analogical conditioning operated in the opposite way to that in which it normally operated only for this verbal class. This is not impossible, since cases where analogy operates bidirectionally are found in the literature (cf. Tiersma 1978; 1982). However, what makes Fiedler's explanation suspicious is the rather ad hoc character of the supposed bidirectional leveling, which is postulated only to explain the occurrence of umlaut in P-Ps. Moreover, Lühr (1987:264) 
objects that this explanation cannot account for the limitation of umlaut to the plural present indicative, which is peculiar to modals. In fact, umlaut does not occur in the singular present indicative either in the case of verbs that display an apophonic alternation such as mag - mögen, kann - können, darf-dürfen or in the case of verbs without such an alternation like er mu $\beta$ - sie müssen, whereas the Rückumlaut-verbs display umlaut in the whole present (cf. er füllt- sie füllen). ${ }^{10}$

The last proposal that will be discussed in this section comes from McLintock (1961), who similarly assumes that an analogical extension of umlaut to the plural present indicative of P-Ps took place. However, McLintock imagines a different model for the four-part analogy. The latter is provided by those inflectional classes in which the stem vowel is identical both in the present indicative and in the present subjunctive (as in the PRES.IND. sie grifent, habēnt vs. the pres.subj. griffèn, habēn, cf. Braune/Eggers 1987:256f.), and particularly by verbs displaying $-\ddot{u}$ - as a stem vowel:

(8) füllent: füllēn $=\mathrm{X}$ (künnen) : künnen

However, this proposal presents more problems than advantages. First, the other inflectional classes display different suffixes in the present indicative with respect to the present subjunctive (cf. ind. -ent vs. subj. - $\bar{e} n$ ), whereas P-Ps are characterized by identical suffixes for indicative and subjunctive (cf. Braune/ Eggers 1987:300). If the four-part analogy were the one represented in (8), one wonders why the suffix -ent of the other inflectional classes was not extended to the P-Ps too. Second, as observed by Lühr (1987:266), this hypothesis does not explain why the four-part analogy concerned only the plural present indicative, leaving the singular present indicative unaltered.

\subsection{Birkmann (1987): The role of system economy}

In the following sections, I will discuss two recent proposals that appeared in the same year, apparently unbeknownst to the respective authors, Birkmann

10. Less convincing is Birkmann's (1987:195) objection to Fiedler's explanation that “offensichtlich eher das Merkmal '+ Umlaut' generalisiert wird und nicht ein bestimmter Präs.-Vokalismus: zu suln/süln gibt es die Varianten soln/söln und bei müezen liegt ein völlig anderer Vokalismus vor als bei den rückumlautenden Verben. Man müßte also Einzelanalogien statt einer Gruppenanalogie annehmen, die dann jeweils auch einzeln motiviert werden müßten". If it is true that an analogical model for müezen was not present among Rückumlaut verbs, it is, however, not difficult to extract from the four-part analogy seen in (6) above a hypothetical feature [+ umlaut] able to trigger the "group analogy". 
(1987) and Lühr (1987). In his impressive 1987 book about P-Ps in the Germanic languages, Birkmann devotes only a small section to the problem of umlaut in the German modals. He first observes that the general process of vowel reduction determined the neutralization of verbal endings in MHG, which became unable to signal the opposition of mood. As a consequence, the latter was carried, where possible, by the stem vowel alternation. Thus, "[ist] die Modus-Opposition am stärksten bedroht bei den schwachen Verben, am besten erhalten ist sie bei den Prät.präs. und im Prät. der starken Verben" (Birkmann 1987:196-197). In (9) the 1st person plural of all tenses and moods of the different inflectional classes is given:

(9)

\begin{tabular}{lllll}
\hline & PRES.IND & PRES.SUB & PRET.IND & PRET.SUBJ \\
\hline P-Ps & turren “we dare" & türren & torste & törste \\
strong verbs & nemen "we take" & nemen & namen & nomen \\
weak verbs & suochen "we search" & suochen & suochten & suochten \\
\hline
\end{tabular}

According to Birkmann, the language system 'reacted' against this state of affairs in two ways. On the one hand, the modals were employed instead of the subjunctive, presumably because they "erstens aufgrund ihrer Semantik dafür prädestiniert sind, zweitens aber auch gerade die Modus-Opposition in ihren Formen zum Ausdruck bringen können” (Birkmann 1987: 197). In this respect, examples can be quoted in which the subjunctive, respectively present and preterit, of a modal verb replaces the subjunctive of a full verb: ${ }^{11}$

(10) i. der heilige engel muoze din gewerte sin unde geleite dich here widere gesunt (Rolandslied 1553f.)

"the holy angel might (lit. must-PREs.suBj) be your protector and might lead (lit. lead-PREs.suBj) you healthy back here"

ii. wie kunde das ergân, daz ich dich minnen solde? (Nibelungenlied 285, 1) "how could it happen that I should love you?"

The second way to express the mood opposition was the use of preterit subjunctive forms instead of the present subjunctive, which "sich wie die Bildung von umschriebenen Formen aus dem drohenden Verlust der Modus-Opposition

11. From the fifteenth century on, the so-called würde-form will assume the role of expressing the subjunctive of a full verb, as is now the case in NHG (cf. Ebert et al. 1993:421). 
erklären [lässt]" (Birkmann 1987: 197). In fact, the neutralization of tense in the subjunctive is a rather old phenomenon; presumably, it first took place in contexts of dubitative or potential meaning, in which "[d]er sogenannte Konjunktiv Präteriti eine größere Entfernung von der Wirklichkeit als die Präsensform [bezeichnete]" (Dal 1966:137). Quite apart from the questions connected with the origin and the causes of the tense neutralization in the subjunctive, it clearly brought about that ...

eine ehemalige Konj.Prät.-Form in Opposition zu Ind.Präs. treten und hier eindeutig Konj. signalisieren [kann], was die alte Konj.Präs.-Form nicht mehr zu leisten imstande war; ich heize (Ind.) ist nicht mehr von ich heize (Konj.), wohl aber von ich hieze unterscheidbar. (Kern \& Zutt 1977:57)

According to Birkmann, this development, which thus concerned the whole verbal system, determined the extension of umlaut to the plural present indicative of the modals, in spite of the fact that the latter preserved a mood opposition between indicative and subjunctive by means of umlaut: "Wenn man nun annimmt, daß die ursprünglichen Prät.-Formen die ursprünglichen Präs.-Formen in dieser Funktion verdrängten, dann waren diese frei und konnten als Ind.-Formen interpretiert werden" (Birkmann 1987: 198). In his view, the change took place as sketched below:

$\begin{array}{llll}\text { PRES.IND } & \text { PRES.SUBJ } & \text { PRET.IND } & \text { PRET.SUBJ } \\ \text { kunnen } & \text { künnen } & \text { kunden } & \text { künden } \\ \text { künnen/künnen } & \text { künenden }\end{array}$

Thus, the extension of umlaut to the plural present indicative of P-Ps happened as a consequence of a slot-exchange of the structuralist type. The functionally non-distinctive form is free to occupy the contiguous slot, replacing the present one. In our case, the present subjunctive form, undermined by the preterit subjunctive form, was functionally free to occupy the place of the present indicative. The linguistic change is therefore explained in terms of chain shifts (cf. Hock 1986: 156ff.). Notice that Birkmann considers his explanation to be morphologically grounded, since it is crucially based on the functional space occupied by morphemes. In addition, he admits that the model of Rückumlaut-verbs, as well as the special semantics of modals, might have played a role (1987: 198). Finally, Birkmann assumes that this process is still going on in NHG, since the preterit subjunctive is now occupying the place of the present indicative (i.e., of the allegedly earlier present subjunctive), as in the case of $i c h$ möchte "I (would) like" with respect to ich mag "I like". 
Several objections, however, can be raised against this explanation. First, as shown in $\$ 2.1$ above, the phenomenon of Rückumlaut cannot be claimed to be available as a model for analogical changes. The second objection is related to a more general question. The explanatory power of chain shifts has intrinsic limits, since the linguistic change is explained in purely structural and intrasystemic terms, without reference to more general notions such as markedness or frequency. Thus, an explanation in terms of push chain, in which the present subjunctive is pushed towards the slot of the present indicative by the preterit subjunctive, is unsatisfactory. ${ }^{12}$ In fact, in the absence of other reasons, it is counter-intuitive to assume that a less frequent form such as the present subjunctive, once it became functionally empty, would have occupied the place of the much more frequent present indicative, as already observed by Behaghel (1928), cf. \$2.1 above. It is more likely that the rare present subjunctive would have disappeared from the system. On the other hand, if an explanation in terms of a drag chain is assumed, then the preterit subjunctive first occupied the place of the present indicative for semantic reasons, as admitted by Birkmann (1987: 198). As a consequence, the place of the present subjunctive could have been occupied by the preterit subjunctive. From this second point of view, the crucial factor triggering the change was what I call a markedness reversal ${ }^{13}$ observed in the case of modals, in which the subjunctive seems to be semantically less (or equally) marked with respect to the indicative. This is a very common phenomenon, and explains why we synchronically observe a change such as the replacement of the present form of mögen by means of the past subjunctive. Under this assumption, the real motivation of the change was not a general phenomenon (i.e., the general employment of the preterit subjunctive to convey irrealis modality), as claimed by Birkmann, but a very specific one, namely the markedness reversal displayed by modals. On closer inspection, the chain shift model adopted by Birkmann is spurious. The machinery is claimed

12. Notice, moreover, that Hock (1986: 157) observes that "There is some controversy as to whether beside drag chains, there can also be push chains. ... The major difficulty with the notion 'push chain', and the reason for its controversial nature is the following: Drag chains are supported by a good deal of empirical evidence, in terms of observable sequences of events. But no such empirical support seems to exist for push chains".

13. For the notion of markedness reversal, also called local markedness (cf. Tiersma 1982), and an extensive discussion of it, cf. Mayerthaler (1981:48ff.): "Intuitiver Hintergrund von Markiertheitsumkehrung ist die Kontextsensitivität von Markiertheitswerten, d.h., daß kontexfrei definierte Markiertswerte in m[arkierteren] Kontexten zu redefinieren sind". 
to function in terms of a push chain, which should assure the morphological motivation for the change. Nevertheless, the markedness reversal between indicative and subjunctive typical of modals constitutes the spur for the present subjunctive to occupy the functional space of the present indicative, which points to a semantically motivated drag chain change, as in the case of NHG mögen/möchten. In this light, it seems that Birkmann too quickly defined his explanation as morphologically grounded. In fact, the real motivation for the change was, on his assumptions, a markedness reversal typical of modals. This is the only way to explain why the present subjunctive did not disappear from the system, but was successful in occupying the privileged place. Finally, the explanation provided by Birkmann fails to answer a crucial question: If the push-drag chain explanation is correct, why did the change concern only the plural present indicative? In the case mentioned above of NHG mögen, the preterit subjunctive is replacing the present indicative in all persons, not merely in the plural. Thus, if Birkmann's approach is able to highlight the role of the markedness reversal typical of modals in favoring the change, his structural explanation does not make clear why the change happened in the way it did. In other words, we have to study all conditions of the system to grasp its dynamics. Birkmann's approach shares the synchronistic shortcomings of classical structuralist linguistics, since it projects the linguistic change onto homogeneous stages, in which we can discretely measure the evolution from one stage to the following. Quite correctly, Lühr (1987) has stressed the chronological differences in the documentation of the umlaut among the several P-Ps; some of them do seem to have undergone the change first. Omitting these relevant data has the consequence of obscuring the teleology of the change, which led Birkmann (1987:219) to the following conclusion:

Wenn man das Eindringen der umgelauteten Formen in den Pl.Präs.Ind. als morphologisch motiviert betrachtet, ... dann liegt hier einer der seltenen Fälle vor, in denen durch morphologischen Wandel morphologische Irregularität aufgebaut wird — aus der Sicht des Gesamtverbsystems.

We will see that the supposed increase of morphological irregularity is a collateral effect of the umlaut extension, although it is not directly connected with the real motivation for the change.

\subsection{Lühr (1987): The role of semantics in local analogy}

Lühr's 1987 analysis follows a rather different line of argumentation than those already discussed. The main concern of her analysis is to make clear which P-Ps 
first underwent the umlaut extension on the basis of historical documentation. In this respect, she observes that the first verb to display any change is mögen, OHG magan. Interestingly, this verb underwent two different kinds of analogical change. On the one hand, magan was reshaped as mugun, with a high back vowel, in the ninth century in Franconian (Tatian, Otfrid), then in Alemannic (ca. tenth-eleventh century, Notker) and in Bavarian (twelfth century). The formal model for this analogical change was provided by the P-Ps of the third and fourth apophonic classes (containing verbs like kunnan and sculan, see (21) below), which also constituted the absolute majority of the P-Ps:

$$
\begin{array}{ll}
\text { scal: } & \text { sculun = mag: X (mugun) } \\
\text { kan: } & \text { kunnun } \\
\text { darf: } & \text { durfun }
\end{array}
$$

In Lühr's view, the four-part analogy does not constitute in itself a crucial factor for the linguistic change to take place. In a process of analogical extension, other kind of similarities and overlap of syntactic and semantic nature are equally important. In this respect, the major syntactic similarity is obviously the fact that most of the P-Ps were modals, i.e., they governed a bare infinitive. From a semantic point of view, Lühr observes that $\operatorname{sculan}^{14}$ and magan overlapped when used as a replacement of the subjunctive in main sentences (cf., e.g., (10) above) to convey wish or exhortation, as in the following examples (cf. Lühr 1987:268):

(13) i. queman mág uns thaz in múat! (Otfrid V,19,36)

"might this come into our hearts!"

ii. druhtin hóhe mo thaz gúat joh frewe mo émmizen thaz múat (ad Ludowicum 6)

"might Lord increase (lit. increase-PREs.subj) his success and always cheer up (lit. cheer up-PREs.subj) his heart"

iii. thes scal er góte thankon (ad Lud. 25)

"he should thank God for this"

iv. thes thánke ouh sin githigini (ad Lud. 26)

"he should also thank (lit. thank-PREs.suBj) his followers for this"

14. According to Lühr (1987:267), the possible model for analogical changes in OHG could only have been sculan, not kunnan, "weil die älteste althochdeutsche Quelle die mugunFormen aufweist, der Tatian kein kan, kunnun kennt und auch für Otfrid nur 5 kan-Belege nachzuweisen sind". 
A second point of semantic overlap concerned the possible use of sculan and magan to convey future meaning (as in the Latin model, cf. Lühr 1987:271):

(14) i. War múgun wir nu bigínnan, mit kóufu brót giwinnan (Otf. III,6,17)

"Where shall we now attempt to get bread by buying"

(cf. Joh. 6,5 unde ememus panem)

ii. thu bist fórsago sín, / thu scalt drúhtine rihten wéga sine (Otf. I,10,19f.)

"You are his prophet, you will prepare the ways for Lord"

(cf. Luc. 1,76 praeibis enim ante faciem domini parare vias eius)

On the basis of these similarities and overlaps, it is thus correct, according to Lühr, to establish the four-part analogy seen in (12) above. Therefore, her approach is based on the fact that ...

es bei der analogischen Umbildung von Modalverben auf Übereinstimmungen in den Bedeutungsmerkmalen ankommt. Nebenbedeutungen eines Modalverbs, die mit den Bedeutungen eines anderen Modalverbs übereinstimmen, können der Anlaß für eine Umstaltung nach diesem Verb gewesen sein.

(Lühr 1987:271-272)

The verb magan underwent a second analogical change attested from the twelfth century on in the Bavarian area: the umlauted form megen, that however occurred alongside mugen forms. In Lühr's reconstruction, the model for the analogical extension was provided in this case by wellen "to want", which presented a phonologically motivated umlaut, i.e. ${ }^{*}$ waljan $>$ wellen (cf. Braune/Eggers 1987:307, Pfeifer 1993:1579). Thus, the proportional analogy was as follows:

$$
\text { will : wellen }=\text { mag: } \mathrm{X}(\text { megen })
$$

With respect to the four-part analogy seen in (12) above, however, the formal matching between the model and the outcome is not complete (I will return to this point later). Besides the formal matching, Lühr highlights the semantic overlap between the two verbs that made the analogy possible. Magan and wellen shared the same semantic overlap seen above, i.e., the usage as a substitute of the subjunctive, the exhortative and the future meaning. Moreover, they shared the meaning "will, wish" as in the following sentence, in which they occur close to each other:

(16) hinder iu wil ih niht bestân: / sît ir ze rîten gerne get, / sô mac ich daz niht lâzen / ich wil mit iu rîten ûf die strâzen (Rabenschlacht I,350)

I do not want to stay after you: since you usually ride with pleasure, I cannot allow it, I will ride with you on the roads" 
In Lühr's view, this sentence shows both hints: magan denotes here both "can, to be able to" and "will". The meaning shift is illustrated in the following way (I quote the whole passage, because it is very telling about her line of argumentation):

'Ich bin zwar befähigt zu einer Tätigkeit, aber es steht in meiner Hand, ob ich die Tätigkeit aus der Möglichkeit in die Wirklichkeit will übergehen lassen'. Der Bedeutungswandel von 'können' zu 'wollen' dürfte sich mithin in der 1 . Person vollzogen haben und die Bedeutung 'wollen' dann auf die anderen Personen übertragen worden sein. (Lühr 1987:274)

In this respect, she quotes 1st plural present indicative forms displaying exhortative meaning also classifiable under the column "will, wish":

(17) Der jude sprach dô: / nû megen wir iemer wesen frô. / daz paradîse ist uns allen ûf getan, / nû megen wir sanfte dar în varn (Kaiserchronik 9458ff.)

"Then the Jew spoke: We will always be happy. The paradise has been prepared for all of us, we can easily enter there"

These points of semantic overlap seem sufficient to Lühr to give rise to the analogical extension wellen $\rightarrow$ megen. Moreover, it is important to recall that the other verb which first underwent analogical extension of umlaut was muozan $\rightarrow$ müezen, already attested in the second half of the twelfth century in the Bavarian area, and displaying, according to Lühr, semantic overlap with respect to megen. Lühr applies this approach to all P-Ps. As a consequence of successive analogical extensions, triggered by similar semantic overlap, the umlaut was extended to all modals in the following way (cf. Lühr 1987:289):

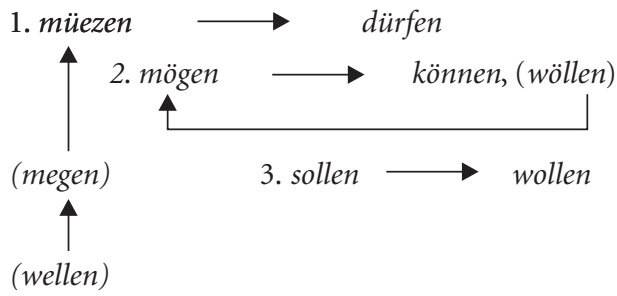

The further steps in this schema represent later developments determined by phonological change and extended analogically to other modals. In particular, at the second step, megen/mügen became mögen under the analogical influence of wellen, which in turn had become wöllen due to phonological change. Subsequently, mögen influenced the change künnen $\rightarrow$ können. Finally, at the third step, the form sollen (remade on the basis of the pret. solte) determined the analogical change wöllen $\rightarrow$ wollen. 
Lühr's contribution is fairly well documented from a philological and a historical point of view. Her observations concerning the earlier attestation of the umlaut extension in the OHG verbs magan and muozan are certainly a remarkable achievement, and will provide the cue - as we will see in the next section - for a new interpretation of the change. However, her explanation of the facts is unconvincing. With respect to previous analyses, she tries to give an answer to the question why umlaut is only found in the plural present indicative. Once more, the explanation is in terms of local analogy. Since wellen displayed umlaut only in the plural present indicative, the latter could be extended to magan. Nonetheless, this explanation raises more questions than it can answer. In fact, one wonders what the object of analogy actually is. Lühr is not very explicit on this point, but we can conceive of two alternatives: Either - $j$ - from ${ }^{\star}$ waljan was analogically extended to magan, giving ${ }^{*}$ magjan $>$ megen; or magun became megen on the basis of the direct (local) model of wellen. According to the first alternative, we have to assume intermediate forms like * magjan and * muozjan, which seem rather improbable, given the late documentation of the phenomenon, and, above all, the fact that the only attested OHG form is wellen with final vowel weakening. Following the second alternative, the object of analogy would have been the (almost completely morphologized) morphophonological alternation $-i$ - [-umlaut $] /-e$ - [+umlaut $]$ in wil/wellen . This alternation is claimed to have been extended, following the proportional analogy represented in (15) above, first to mag/megen, and hence to muoz/müezen. In my opinion, there is strong counter-evidence against this hypothesis. The morphophonological — and therefore only partially/no longer phonologically motivated - alternation is anything but salient in the model verb wellen. In fact, it appeared only in the case of strong verbs like helfen "to help" - hilfst "thou help" - hilft "s/he helps", where, however, it concerned vowel alternation in the singular, not in the plural present indicative (cf. Bittner 1996:75ff.). ${ }^{15}$ Moreover, the four-part analogy of (15) is imperfect, because the inflectional paradigms to which magan and wellen belonged in MHG were different. In fact, the plural present indicative of wellen presented different suffixes with respect to magan (cf. wellent vs. megen). Thus, one wonders why the object of

15. An anonymous reviewer objects that helfen cannot be conceived as a possible model for wellen, since helfen displayed the mid-low vowel /ë/ with respect to the mid-high /e/ of wellen. However, in Upper German dialects, and especially in Bavarian (cf. Schirmunski 1962:243), /ë/, present in helfen, and the (umlauted) /e/ of wellen merged (cf. Paul/Wiehl/Grosse 1989: 170). 
analogy was only the less salient umlaut and not a form like wellent, or why the whole paradigm of magan was not completely remade as ${ }^{*}$ mig/megen on the basis of wil/wellen. If my reconstruction is correct, her idea is thus that the analogical extension was strictly local (i.e. syntagmatic) and concerned the plural (or even the 1st person present indicative, as observed by the author) of wellen and magan. Once megen came up as a mistake, i.e., as an analogical extension, it was immediately reanalyzed as an umlauted form with respect to the singular present indicative mag, hence it was later extended to müezen de dicto, i.e., as a paradigmatic alternation of umlaut, not de re, i.e., as a phonetic form -e-, erroneously created owing to the textual (and semantic) contiguity of megen and wellen. The main weakness of Lühr's line of argumentation lies, in my opinion, in the misconceived role of analogy, which is merely seen in terms of syntagmatic erroneous over-extension, and of the speaker, who must carry out a very complex process of reanalysis on the basis of a not very salient model. ${ }^{16}$

\section{The system of P-Ps in the history of German}

In what follows, I will try to approach the problem from a wider perspective. In fact, all the attempts discussed above only focus specifically on P-Ps, without considering their paradigmatic relations with the other verbal classes. It is my opinion that an explanation of the problem can be found if the paradigmatic properties of P-Ps are compared with the rest of the OHG verbal classes.

I have already mentioned that P-Ps first originated in the Indo-European mother tongue. In particular, the oldest representative of the class, which constituted the model for forming the other P-Ps (cf. Meid 1971: 18ff.) and can be considered the inflectional model for the whole class, is - quite paradoxically — the only non-modal P-P in NHG, i.e., wissen (cf. Ramat 1971; 1986: 187). Let us take a look at the structure of the OHG verbal classes (cf. Braune/Eggers 1987:256f.):

16. For other criticism against Lühr's proposal, mainly drawn from Low German dialects, cf. Beckmann (1990:56ff.). 
(19)

\begin{tabular}{|c|c|c|c|c|}
\hline & & P-Ps & strong verbs & weak verbs \\
\hline INF & & wizzan "to know" & grīfan "to grasp" & habèn "to have" \\
\hline \multirow[t]{4}{*}{ PRES.IND } & $1 / 3$ sG & weiz & grīfu, grīfit & habèm, habèt \\
\hline & $2 \mathrm{sG}$ & weist & $\operatorname{gri} f i s(t)$ & $h a b \bar{e} s(t)$ \\
\hline & $1 \mathrm{PL}$ & wizzun & grīfen & habèn \\
\hline & $3 \mathrm{PL}$ & wizzun & grïfent & habēnt \\
\hline PRES.SUBJ & $1 \mathrm{sg}$ & $w i z z i$ & grīfe & habe \\
\hline \multirow[t]{3}{*}{ PRET.IND } & $1 / 3 \mathrm{sG}$ & westa/wessa & greif & habèta \\
\hline & $2 \mathrm{sG}$ & westōs $(t) /$ wessōs $(t)$ & grife & habētōs $(t)$ \\
\hline & $1 \mathrm{PL}$ & westun/wessun & grifun & habētun \\
\hline PRET.SUBJ & $1 \mathrm{sg}$ & westi/wessi & grifi & habèti \\
\hline
\end{tabular}

On the basis of wizzan, and bearing in mind the other inflectional classes of OHG verbs, let us try to determine the morphological characteristics of P-Ps in OHG. The following Inflectional Features (= IFs) keep P-Ps clearly distinct from the other verbal classes:

(20) IF1 -Ø/1/3PS.SG.PRES.IND

(similar to the PRET.IND of strong verbs);

IF2 - $t$ /2PS.SG.PRES.IND

IF3 Vowel Alternation/sG.PREs.IND

( similar to the PRET.IND of strong verbs, cf. greif/grifun);

IF4 -n/1/3Ps.PL.PRES.IND

(in the other classes, a 1. PL.PRES.IND $-n$ is opposed to $3 \mathrm{PL}-n t$ );

IF5 -i-/sUBJ

(similar to the PRET.SUBJ of strong verbs)

Similar IFs are also found in other inflectional categories, e.g. the Vowel Alternation in sg.pres.ind. is also found in the preterit indicative of strong verbs. The crucial point, however, is that their clustering clearly identifies the paradigm of a P-P. In other words, P-Ps constitute a specific microclass of the OHG verbal system. Microclasses are particular inflectional classes that are numerically small. Generally, they are competing with other macroclasses ${ }^{17}$

17. On other possible interpretations of the notion of macroclass, cf. Carstairs (1986, 1987:248ff.), and the criticism in Gaeta (1995). 
unless they are identified by specific extra-morphological properties. Competition with a macroclass often has the effect of decreeing the death of a microclass, whose members tend to be absorbed by the competing macroclass (cf. Wurzel 1989:121ff. for details). On the other hand, if it is clearly identified by specific extra-morphological properties, a microclass has a good chance of being stable and also of becoming productive. ${ }^{18}$ Extra-morphological properties that can relate to morphological properties are either phonological (e.g., the ending of the basic lexical form) or semantico-syntactic (e.g., semantic features like 'animateness', 'stativeness', etc., cf. Wurzel 1989: 113; 1987a: 76ff.). The notion of inflectional class stability is crucial to determining what is normal in an inflectional paradigm. From this viewpoint, consider that wizzan has developed preterital forms by means of the dental suffix typical of weak verbs (cf. (19) above). ${ }^{19}$ As is well known, the latter have been and still are the most productive inflectional class of German verbs. This tells us that weak verbs must be considered the "default" verbal class, i.e. the verbal class that is fully stable, which is intended as a form of system-dependent naturalness in morphology: ${ }^{20}$

$[\mathrm{M}]$ arkedness is the negative counterpart of naturalness ... Class stability is a form of system-dependent naturalness in morphology. Stable inflectional classes are unmarked and unstable inflectional classes are marked ... This is reflected by the fact that when a stable and an unstable complementary class correspond, only the words of the marked class have an explicit statement as inflectional class in the lexicon, whereas the inflection of the words of the unmarked class follows automatically. (Wurzel 1989:129)

Thus, when P-Ps had to remake a preterital form, the default way was chosen, i.e. the dental suffix of weak verbs added to the stem of the plural present indicative.

Let us look now at the whole microclass, as documented in OHG times and given according to the original apophonic classes (so-called Ablautreihen) to which they belonged in PGmc. (cf. Braune/Eggers 1987:299ff.):

18. However, class stability and productivity do not necessarily coincide; cf. Wurzel (1989: 150f.).

19. However, alongside the new dental form westa, the old form wessa (cf. Goth. wissa, Braune/Ebbinghaus 1981:127) is still documented (cf. Braune/Eggers 1987:300). Old preterit forms are also attested for muozan (cf. muosa). See Bittner (1996: 128ff.) for details.

20. For a presentation and a general discussion of Natural Morphology, the reader is referred to Dressler et al. (1987). 
(21)

\begin{tabular}{|c|c|c|c|c|c|}
\hline \multicolumn{2}{|c|}{ Ablautr. INFINITIVE } & \multirow{2}{*}{$\frac{\text { PRES.IND.SG/PL }}{\text { weiz/wizzun }}$} & \multirow{2}{*}{$\begin{array}{l}\text { PRET.IND } \\
\text { wissa/wessa } \\
\text { (later westa) }\end{array}$} & \multirow{2}{*}{$\begin{array}{l}\text { PAST PART. } \\
\text { giwizzan }\end{array}$} & \multirow{2}{*}{$\begin{array}{l}\text { MEANING } \\
\text { "to know" }\end{array}$} \\
\hline I. & 1. wizzan & & & & \\
\hline & 2. - & eigun & - & eigan (adj.) & "we own" \\
\hline II. & 3. - & toug/tugun & tohta & - & “it helps" \\
\hline \multirow[t]{4}{*}{ III. } & $\begin{array}{l}\text { 4. unnan } \\
\text { gi-unnan }\end{array}$ & $\begin{array}{l}\text { an/unnun } \\
\text { gian/gunnun }\end{array}$ & $\begin{array}{l}\text { onda } \\
\text { gionsta (gunde) }\end{array}$ & - & "to grant" \\
\hline & 5. kunnan & kan/kunnun & konda $($ kunda $)$ & - & $\begin{array}{l}\text { "to understand, } \\
\text { can" }\end{array}$ \\
\hline & 6. durfan & darfldurfun & dorfta & - & "to need" \\
\hline & 7. - & gitar/giturrun & gitorsta & gitorran & "to dare" \\
\hline \multirow[t]{2}{*}{ IV. } & 8. scolan/sculan & scal/sculun & scolta & - & "to have to" \\
\hline & 9. - & ginah & - & - & "it is enough" \\
\hline V. & $\begin{array}{l}\text { 10. magan } \\
\text { mugan }\end{array}$ & $\begin{array}{l}\text { mag/magun } \\
\text { mugun }\end{array}$ & $\begin{array}{l}\text { mahta } \\
\text { mohta }\end{array}$ & - & $\begin{array}{l}\text { "to be able to, } \\
\text { can" }\end{array}$ \\
\hline VI. & 11. muozan & muоz/muоzип & $\begin{array}{l}\text { muosa } \\
\text { (later muosta) }\end{array}$ & - & $\begin{array}{l}\text { "to have the } \\
\text { possibility, may" }\end{array}$ \\
\hline
\end{tabular}

Notice first that the number of verbs belonging to the class of OHG P-Ps is larger than that of the verbs shown in (1) for NHG. Moreover, while NHG P-Ps are virtually all modal verbs, with the sole significant exception of wissen, the OHG class of P-Ps also contained a number of non-modal verbs (cf. torran, tugan, unnan, and — only partially attested — ginah and eigun).

With respect to the system of P-Ps as documented for Goth. (cf. Braune/Ebbinghaus 1981:126ff.), other P-Ps not displaying modal characteristics have disappeared, such as the Goth. verb ōg/oggun/ōhta "to fear". Notice, moreover, that Goth. ogan belonged to the sixth apophonic class, and therefore did not display stem vowel alternation in the singular with respect to the plural present indicative and the infinitive, i.e. IF3 of (20). Thus, what we observe in OHG is a certain tendency towards the definition of a cluster of conditions grouping the microclass of P-Ps round a set of specific properties. In this perspective, consider that magan has developed in OHG forms with a back vowel not attested in Goth., where the paradigm of this verb was mag/magun/mahta (cf. 
Braune/Ebbinghaus 1981:128f.). In other words, magan improved its status with respect to IF3, developing a stem vowel alternation in the singular with respect to the plural present indicative and the infinitive. However, according to the documents, the situation is still rather unstable for this verb, since the form magan is well preserved, especially in Upper dialects such as Bavarian (cf. Braune/Eggers 1987:302). Finally, the other verb that appears to diverge from some of the IFs in (20) is muozan, since it does not display IF3 either. Apart from these two cases, the OHG system of P-Ps is well captured by the IFs in (20). Moreover, the majority of P-Ps were characterized by the stem vowel alternation $-a-/-u$ - between the singular and the plural present indicative and the infinitive. This alternation type was considerably salient, since the only P-Ps that did not display - $a-/-u$-alternation were wizzan, magan (but cf. mugun) and muozan.

In addition to the group of P-Ps, let us now consider the characteristics of the modal verb wellen "to want", which did not belong to the class of P-Ps. The inflectional paradigm of this verb has a particular story, since the present form originates from an old optative of the old athematic class of the so-called mi-ending verbs (cf. Braune/Eggers 1987:307). It consequently displayed the endings that usually appeared in the preterit subjunctive of the other inflectional classes. Moreover, the preterit was formed by means of a dental suffix, as in the other modals, on the model of the class of weak verbs. To emphasize the linguistic changes that occurred in OHG, the paradigm of wellen will be presented next to the corresponding Goth. wiljan (cf. Braune/Ebbinghaus 1981:130):

\begin{tabular}{llll}
\hline INF. & & OHG wellen & Goth. wiljan \\
\hline PRES.IND & $1 \mathrm{SG}$ & willu/wili/wile & wiljau \\
& 2. & wili/wile/wilis & wileis \\
& 3. & wili/wile/wilit & wili \\
& $1 \mathrm{PL}$ & wellemēs, wellèn & wileima \\
& 2. & wellet & wileina \\
& 3. & wellent & - \\
PRES.SUBJ & $1 \mathrm{SG}$ & welle & wilda \\
PRET.IND & $3 \mathrm{SG}$ & welda/welta & wildèdjau / wildèdi \\
PRET.SUBJ & $1 / 3 \mathrm{SG}$ & wolti &
\end{tabular}


From the comparison between the Goth. and the OHG forms, it becomes evident that wellen has undergone a number of changes, which brought it near to the inflectional class of P-Ps on the one hand, and to the weak verbs on the other. In fact,

im Got. flektierte wiljan wie die Prät.präs. im Präs.Konj. bzw. wie die starken Verben im Prät.Konj.; im Ahd. sind diese Konj.-Formen dagegen nur noch im Sg.Präs.Ind. teilweise erhalten, im Pl.Präs.Ind. wurden sie durch die Endungen der schwachen Verben Klasse 1 ersetzt. (Birkmann 1987:157)

Notice that in the present indicative the stem vowel alternation $e / i$ between singular and plural occurs, which is unusual among the other P-Ps, but which corresponds to the IFs of the inflectional class and in particular to IF3 above. The origin of this stem vowel alternation is phonological (cf. ${ }^{*}$ waljan $>$ wellen), as I mentioned in $\$ 2.3$ above. Thus, wellen presents the following picture with respect to the IFs seen in (20) above: ${ }^{21}$

$$
\begin{aligned}
& \text { IF1 -Ø/1/3Ps.SG.PRES.IND } \\
& \text { NO!: } \text { will- } u \text { vs. wil- } i \\
& \text { IF2 -t/2PS.sG.PRES.IND } \\
& \text { NO!: wil-i } \sim-e \sim-i s \\
& \text { IF3 Vowel Alternation/sG.PRES.IND } \\
& \text { YES: will- vs. well- }
\end{aligned}
$$

IF4 -n/1/3PS.PL.PRES.IND

NO!: well-emēs wellēn vs. wellent

From (23) it emerges that wellen displays a rather mixed paradigm: with respect to the IFs of P-Ps, only one property is shared. The wellen case, as well as the comparison with the set of Goth. P-Ps, helps one draw the conclusion that there is a conspiracy towards a reanalysis of the original class of P-Ps as being identified with the class of modals. In fact, given the syntactic (they govern a following bare infinitive) and semantic (they deal with modality) properties of modals, which constitute the absolute majority of P-Ps, we can state that the inflectional class originally containing P-Ps has acquired a new extra-morphological motivation (cf. Wurzel 1989: 144f.). According to the model of Natural Morphology adopted by Wurzel, an extra-morphologically motivated inflectional

21. The subjunctive, as well as the plural present indicative, were remade in OHG following the productive model of weak verbs (welle/ welti, cf. Braune/Eggers 1987:307). Therefore, it will be left aside in the following discussion. 
class has a good chance of becoming stable, even if it happens to be rather small, as in the case of modals. An extra-morphologically motivated inflectional class can be represented in implicational terms by means of a Paradigm-Structure Condition (= PSC), which helps one identify the basic properties for a verb to be assigned to an inflectional class:

$$
\text { PSC: }\left[\begin{array}{c}
\mathrm{V} \\
+ \text { modal }
\end{array}\right] \supset\left\{\begin{array}{l}
\text { IF1-- } \varnothing / 1 \text { //3.PS.SG.PRES.IND. } \\
\text { IF2--t/2.PS.SG.PRES.IND. } \\
\text { IF3--VA/sG.PrEs.IND. } \\
\text { IF4--n/1./3.PS.PL.PRES.IND. } \\
\text { IF5--i-/sUBJ. }
\end{array}\right\}
$$

PSCs can be understood as a way of organizing the inflectional structure of a language, so that they are not distributed randomly, but are grouped in a set of implications. As repeatedly observed by Wurzel (1989:113; 1987a:77; 1987b; 1994a: 45), PSCs are an important tool serving the speakers' knowledge of their morphology. In general, PSCs warrant the accessibility and the learnability of an inflectional system, since the child tries to keep the expenditure of learning a system where it is not generally predictable which inflectional rules apply to a given word as low as possible "by determining and generalizing relations between the independent extra-morphological and the morphological properties of words or, if this is not possible, between the different morphological properties of words" (Wurzel 1989:113). Inflectional classes related to a PSC also have a good probability of becoming productive. In this respect, consider the case of NHG brauchen "to need", which is on its way to being included in the set of modals. At a sub-standard level, this verb has already acquired peculiar properties of modals, since it can govern a bare infinitive and presents a zero suffix in the 3rd singular present indicative, as in Er brauch nicht kommen "he need not come" (cf. Wurzel 1989:145, 179). ${ }^{22}$ Thus, an apparently contra-iconic linguistic change such as braucht $>$ brauch, in which an overt, additive suffix is replaced by a zero morpheme, is motivated by a tendency toward adapting to the IFs of the class acting as a pole of attraction, which is expressed by means of an extra-morphologically motivated PSC. Thus, the PSCs structure the inflectional system of a language, i.e. they establish the system-dependent naturalness and provide the base for evaluating the system adequacy of a single paradigm with respect to the general

22. For the partially similar development of English to need, cf. Plank (1984). 
inflectional structure of a language. Therefore, we can on the one hand formulate the prediction that verbs not sharing the extra-morphological properties of the inflectional class (i.e. the non-modal verbs) will be eliminated. This prediction is borne out by the data, since we observe that non-modal P-Ps (cf. OHG torran, tugan, gi-unnan > NHG törren, tügen, gönnen) have given up the inflectional properties of P-Ps, and behave in NHG as weak verbs (cf. ich gönne, du gönnst, er gönnt, etc.). Moreover, the nonmodal P-Ps that displayed only a few attested forms (cf. OHG eigun, ginah) have completely disappeared. While that could conceivably be an accident, the fact that they actually died out a little later suggests that their sparse attestation really means that they were already passing out of use. On the other hand, we can predict that verbs provided with the extra-morphological properties of the inflectional class will also adapt to its IFs. As an example, consider the IF2, according to which verbs belonging to this inflectional class display a single suffix $-t$ in the 2PS.SG.PRES.IND, whereas all other inflectional classes present a common suffix - st. The modal verb wellen carried over the suffix $-t$ in the 2PS.SG.PRES.IND wilt in MHG. With respect to the picture seen in (23) above, wellen has thus continued the process of adapting to the IFs of modals:

\section{IF1 -Ø/1/3PS.SG.PRES.IND \\ YES: wil (beside wile) \\ IF2 - $\mathrm{t} / 2$ PS.SG.PRES.IND \\ YES: wilt \\ IF3 Vowel Alternation/sG.PRES.IND \\ YES: will- vs. well- (in Franconian the form woll- is found) \\ IF4 -n/1/3PS.PL.PRES.IND \\ NO!: wellen vs. wellent (but the 3Ps.PL wellen is also attested)}

Apart from IF4, which is also gradually being acquired, and IF5, as remarked in note 16, all other IFs of modals are present. ${ }^{23}$ Thus, all these changes are explained by a tendency towards improving the system-dependent naturalness

23. Notice that some problems in the structure of the paradigm of wellen may be created by the Franconian forms with a back vowel, cf. wollen, etc., which are now common in NHG. These forms are probably due to the influence of the following /1/, and of sollen (cf. Fertig 1999:244; 2000:74 for details). Moreover, this extension was favored by the tendency towards rounding due to the initial labial glide; in addition, the influence of the model of the other modals with a back vowel in the preterit and in the plural present indicative cannot be excluded (cf. Paul/Wiehl/Grosse 1989:267). The latter factors can also be made responsible for the diffusion of a preterit form with back vowel in the case of wissen (cf. wusste). 
of the morphological system. In other words, they are instances of natural morphological change, which "is characterized by the fact that words will change from the less normal to the more normal inflectional class; systemdependent markedness is eliminated by change of class" (Wurzel 1989:70).

\subsection{Umlaut extension as natural change}

A peculiar trait of OHG P-Ps/modals was the suffix - $i$ - as a marker of subjunctive in all tenses (cf. IF5 in (20) above). It has already been observed (see $\$ 2.2$ above) that this feature represented a defining property of modals. For the latter, in contrast with the other inflectional classes, the suffix can be considered a uniform marker in the sense of Mayerthaler (1987:49), since it uniformly designated one and the same morphological category. In addition, this marker was unambiguously used to mark subjunctive in the other verbal classes too (cf. (19) above). Thus, we can say that the peculiar semantic trait of modals, which can also be interpreted as a markedness reversal between indicative and subjunctive (see $\$ 2.2$ above), is mirrored by the paradigmatic strength of the subjunctive suffix $-i$-, which was a uniform marker in this class. From this viewpoint, the possible interference of the subjunctive suffix in the modals' paradigm is not surprising, given its strength as a uniform marker and the particular semantics of the modals. Note that this position is the opposite of that held by Birkmann (for which see $\$ 2.2$ above) who contended that the weak perceptibility of the present subjunctive in the whole inflectional system (and consequently in the modals too) determined its general replacement by means of the better distinguished preterit subjunctive. In the inflectional paradigm of the modals, the subjunctive suffix $-i$ - constitutes a stable and strong marker; moreover, its paradigmatic strength reflects the particular extra-morphological property of modals, in which a markedness reversal between indicative and subjunctive is found. Thus, any possible over-extension of the stable marker is to be expected in the system of modals. One must add that the only other case in which - $i$-appears as an inflectional suffix in the verbal system is the preterit subjunctive of strong verbs and of weak verbs (cf. grifi and habèti in (19) above). In other words, this suffix is always associated with categories conveying irrealis modality. It is natural to conclude that this fact also might play a role in favoring interferences in the case of modals, which often conveyed irrealis modality. Finally, recall that the suffix $-i$ - caused phonological umlaut in $\mathrm{OHG}$, which was successively morphologized in MHG due to the radical weakening of final vowels. As a consequence, the properties once belonging to the suffix - $i$ - 
are transferred to the umlaut marker, i.e., the vowel alternation. ${ }^{24}$ These circumstances and the properties of the modals' morphosemantic class shed light on the presence of umlaut in the present indicative. They provided the necessary conditions for the extension of umlaut from the subjunctive to the indicative to take place. ${ }^{25}$ However, this is not sufficient. There are still some problems to explain. First, we have seen that the extension of umlaut was not a simultaneous process. In fact, it first concerned the OHG verbs magan and muozan, and was then extended to the others. Moreover, it did not cause a full reanalysis of the paradigms of P-Ps. The umlaut was only extended to the plural present indicative (and hence to the infinitive), although it is theoretically possible that the subjunctive completely replaced the indicative, given the markedness relations between the moods. Actually, this is what happened in PGmc. in the case of wollen, in which the optative form completely replaced the indicative, as attested by Gothic (cf. (22) above). Moreover, this is what we observe in NHG, in which, as mentioned in $\$ 2.2$ above, the preterit subjunctive of mögen, i.e. ich möchte, $d u$ möchtest, etc., is on the way to completely replacing the present indicative. To explain why umlaut first extended to the plural present indicative of the verbs mögen and müssen, we have to address our attention to the IFs of this inflectional class seen in (20) above. The OHG verbs magan and muozan presented the following picture (cf. (21) above):

$$
\begin{aligned}
& \text { IF1 - } / 1 / 3 \text { Ps.sG.PRES.IND } \\
& \text { YES: mag, muoz } \\
& \text { IF2 -t/2PS.sG.PRES.IND } \\
& \text { YES: } \text { maht, } \text { muost }{ }^{26}
\end{aligned}
$$

24. For this interpretation of umlaut, cf. Ronneberger-Sibold (1990b).

25. As the reader may note, we are here on the opposite side with respect to what Behaghel claimed on the present subjunctive and reported in $\$ 2.1$ above. However, Behaghel's observation that present subjunctive forms were quite rare in OHG is essentially correct. What he missed seeing was the strict connection between the uniform subjunctive marker $-i$ and the class of modals.

26. The form maht is the result of general phonological processes of devoicing and spirantization (cf. Braune/Eggers 1987: 139); the form muost comes from an assimilation rule of the otherwise palatal sibilant to the following dental (cf. Braune/Eggers 1987:168). These allophonic processes are irrelevant for morphology, because they do not give rise to paradigmatic alternations. But discussing this aspect would take us too far away. See, however, Dressler (1985: 76ff.). 
IF3 Vowel Alternation/sG.PREs.IND

NO!: mag-vs. mag-; muoz- vs. muoz-

IF4 -n/1/3Ps.PL

YES: magun; muozun

IF5 -i-/sUBJ

YES: megi/mehti; müezi/müesi

As is shown in (26), magan and muozan are the only two P-Ps that in OHG did not fit completely with the IFs of this inflectional class. In particular, they did not display IF3, i.e. the stem vowel alternation condition, which is present in all others verbs of the class (cf. (21) above). At least for magan, the tendency towards adapting to the IFs led to the creation of an analogical form mugun in some German dialects (notably in Franconian, see $\$ 2.3$ above). However, with respect to the complicated analogical mechanism proposed by Lühr (1987), the morphological change appears now to be motivated by the need for improving the system adequacy of the verb. In this perspective, the change increased the naturalness (or diminished the markedness) of the whole system. The model that gave rise to the form mugun was the most widespread within the inflectional class of P-Ps (cf. an/unnun, kan/kunnun, darfldurfun, gitar/giturrun, scal/sculun). Besides mugun, we have already seen in $\$ 2.3$ above that Bavarian dialects developed a form megen, which was the result of the extension of umlaut. This new form also improved the system adequacy of the paradigm of magan, since it established a stem vowel alternation between the singular and the plural present indicative. The latter is also true of the other verb that first underwent the linguistic change, namely muozan. The umlauted form müezen, first attested in Bavarian dialects as well, established a stem vowel alternation in the singular with respect to the plural present indicative and to the infinitive, and rendered the verb fully congruous with the IFs of the inflectional class, as already observed by Birkmann (1987:216), who concluded that:

andererseits aber auch im Präs.Ind. durch das Eindringen des Umlauts in den Pl. Irregularität aufgebaut wird. Daneben stellt der Vokalwechsel ein wichtiges Merkmal der Flexionsklasse der Prät.präs. dar, und müezen erfüllt als Modalverb die Bedingung für die Flexionsklassenzugehörigkeit.

He maintains, however, that umlaut extension represented an unmotivated increase of irregularity within the system, as already discussed in $\$ 2.2$ above. Only for muozan might the linguistic change have brought benefits in terms of improving the system adequacy of the verb. The other parallel case of magan is completely ignored. Consider that for magan two different possible changes are 
attested to improve its system adequacy. They belong to two different times and to two different geographical areas:

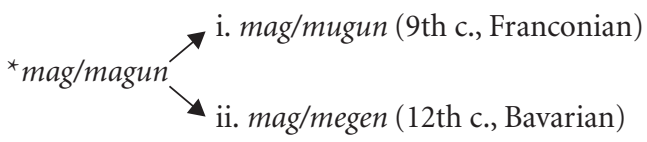

While the first change (mag/mugun) can be ascribed to OHG times and to a Franconian area, the second case (mag/megen) came up in MHG times and in a Bavarian area. ${ }^{27}$ For muozan only the second possibility, i.e. muoz/müezen, is attested. The first one (cf. ${ }^{\star}$ maz/muozun as scal/sculun) is precluded by the absence of a direct model containing a stem diphthong. In fact, muozan is the only verb of the sixth apophonic class attested in OHG (cf. (21) above). Moreover, in a possible change ${ }^{\star}$ maz/muozun, the direction of the process of analogical extension would have been the opposite to what we observed for magan, since the plural form would have induced the reshaping of the singular. Far from disconfirming the predictions made by Natural Morphology, umlaut extension can be reconducted to the inner tendency of the MHG inflectional system towards eliminating marked morphological features from the stable microclass of modals identified by a clear PSC. In other words, umlaut extension must be considered a natural morphological change.

\subsection{Where does umlaut really come from?}

We have so far explained why the change took place in the way it did in terms of improvement of system adequacy of the two verbs that first underwent it. Let us now try to speculate on how the extension might really have taken place. Notice, incidentally, that the following explanation is not immediately connected with the morphological approach to umlaut extension adopted in the previous section.

Recall that we have seen that the umlaut rule in OHG took as its domain the phonological word (cf. $\$ 2.1$ above), potentially giving rise to neutralizations between the indicative and the subjunctive in presence of an umlaut-triggering clitic in late OHG, when the radical weakening of unstressed vowels and the

27. The NHG form mögen goes back to a hypercharacterized mixture of the two possibilities, cf. mügen, with the addition of the lowering of the stem vowel (for a discussion of these problems, cf. Fertig 1999:242; 2000:72). 
generalization of nonprimary umlaut took place. The latter phenomena concerned the forms megen and müezen. This calls to mind Brenner's (1895) and Behaghel's (1928) idea, according to which umlaut first arose as a consequence of a postposed clitic. The fact that, as has been objected (cf. Ščur 1961:209), umlaut in external sandhi was only sporadically attested in OHG and successively disappeared does not really constitute a true counter-argument. As discussed in $\$ 2.1$ above, it is quite usual for phonological processes having a domain wider than the prosodic word to be either not shown in writing or shown much less frequently and consistently, since they do not give rise to paradigmatic alternations. From this point of view, the attestations of umlaut in external sandhi are surprisingly numerous, and vouch for the wide diffusion of the phenomenon in OHG times.

In my opinion, the occurrence of umlaut in external sandhi must be seen in terms of a neutralization of both phonological and morphological features. In fact, the phonological process of umlaut determined the neutralization of the phonological feature [ \pm front] in the case of a following non-consonantal, high and front segment. This process was a source of morphological opacity within paradigms. Umlaut triggered by a postposed clitic caused the neutralization of the opposition between the present indicative and the present subjunctive of modal verbs, since the latter were the only class that displayed the suffix $-i$ - in the present subjunctive. This neutralization of a phonological origin favored the process of umlaut extension, together with the other factors examined above. In particular, consider the paradigmatic strength of the subjunctive marker $-i$ within this inflectional class and the markedness reversal between indicative and subjunctive mood. As seen in $\$ \$ 2.2-3$ above, the subjunctive occurred in main clauses conveying an exhortative, desiderative or future meaning, often joined with an allocutive function. In several cases, and particularly those in which the allocutive function was dominant, the pronoun was postposed, especially in the 1st person plural where cliticization accompanied by syllable reduction is often documented. ${ }^{28}$ Clearly, a complete neutralization between

28. Cf. the examples in (14i), (17) above, and the following example from Konrad v. Fußesbrunnen's Kindheit Jesu: muge wir doch gên unde besehen, wie vil der unsern sî erslagen "let us go and see how many of our (men) they killed", displaying the optional nasal deletion. In this respect, consider similar interferences between indicative and subjunctive observed in several dialects of central Italy. In these cases, the preterit indicative has been replaced by the preterit subjunctive, but only in the 1st and in the 2nd person plural (cf. jéssimo, iéssivo vs. jéttero da jícce "to go"), presumably because, among other things, "[d] urch seinen Gebrauch in hortativen (1. Person) bzw. optativen (2. Person) Kontexten dieser Konjunktiv besonders 
indicative and subjunctive took place in these contexts, both at a formal and at a semantic level. Notice that the same does not hold true for the singular forms (cf. (3) above). Thus, it was the phonological process of neutralization that determined the emergence of the umlauted forms in the plural present indicative. However, it must not be forgotten that the phonological neutralization had precise correspondences at the functional (i.e. markedness reversal between indicative and subjunctive in modal verbs) and at the morphological level (i.e. the strength of the subjunctive marker - $i$ - in modals). This state of affairs favored (or rather triggered) the linguistic change, but did not determine the manner and the outcome. In fact, the reanalysis and the restructuring of the paradigm first took place in cases where it was necessary to establish a full system adequacy with respect to the IFs, i.e. in the two incongruous OHG verbs magan and muozan. In the latter, the umlauted forms were able to eliminate the morphological inadequacy, i.e. the absence of IF3. Similar to what we observe in Upper German dialects for other highly frequent verbs such as to go, to do, to stay (cf. \$2.1, and Schirmunski 1962:500ff.), they were extended to the other modals, in which, however, the phonological and functional neutralization of indicative and subjunctive was already present.

Moreover, OHG was probably the only Germanic language in which umlaut acted at the level of the phonological word. This explains why the extension of umlaut concerned all modals besides the two verbs magan and muozan in which it was morphologically motivated. In fact, in other Germanic languages, morphological changes of a similar type to what we observed for German are found, which aimed at improving the status of these verbs with respect to the IFs of the verbal class. In particular, the North Germanic languages displayed both the type mag/mugun (cf. OSw. ma/mughum, ODan. ma/mughom) and the type mag/megen (OIc., ONorw. málmegum). Notice that in the North Germanic languages ${ }^{\star}$ magan is the only P-P that is inadequate with respect to the IFs since the other Germanic verb * mōtan, corresponding to NHG müssen, is not attested (cf. Birkmann 1987:362). That the teleology of these changes is the same as for German is confirmed by a look at the set of P-Ps attested in for instance - OSw. and OIc. (cf. Birkmann 1987:223, 293): ${ }^{29}$

häufig [ist]" (Haase 1996:74).

29. For a wider discussion of P-Ps in North Germanic languages, and especially in Icelandic, cf. Gaeta (2000). 
(28)

\begin{tabular}{lll}
\hline Germanic P-Ps & OIc. & OSw. \\
\hline${ }^{*}$ witan & veit-vitum & vet-vitum \\
${ }^{*}$ igan & á-eigum & a-äghum \\
${ }^{*}$ kunnan & kann-kunnum & kan-kunnum \\
${ }^{*}$ unzan & ann-unnum & an-unnum \\
${ }^{*}$ purban & parf-purfum & parf-porvom \\
${ }^{*}$ munan & man-munum & mon-monom \\
${ }^{*}$ skulan & skal-skulum & skal-skulum \\
${ }^{*}$ magan & má-megum & ma-mughum \\
\hline
\end{tabular}

In particular, in the case of OIc. megum the presence of an umlauted vowel ${ }^{30}$ is probably due to the same factors summarized above for German, as - at least partially — admitted by Birkmann (1987:230):

Unserer Meinung nach liegt im Falle von urn. ${ }^{\star}$ magum $>$ aisl. megum morphologischer Wandel vor, ein Wandel, der für dieses Verb eine Zunahme an Irregularität, aber zugleich eine Anpassung an die Flexionsklasse der Prät.präs. bedeutet, da durch ihn eine Vokalalternation zwischen Sg. and Pl.Präs.Ind. entsteht.

OIc. did not, however, crucially display phonological neutralization as a consequence of postposed clitic pronouns since the latter were not umlauttriggers (cf. vér, pér, peir, pau). Therefore, the umlaut in megum was not extended to the other modals, presumably because the functional neutralization between indicative and subjunctive was not accompanied by a general phonological neutralization due to a postposed clitic, as in the case of OHG. Thus, a peculiar characteristic of OHG, i.e. the pervasive action of umlaut in the domain of the phonological word, explains why the story of German modals displays a significant difference with respect to other North Germanic languages, although the local morphological motivation of the change was essentially the same.

30. Cf. Noreen (1923:352): "Der auffällige stamm meg- stammt wol aus dem konj., der einst * megja gelautet haben muss". 


\subsection{Further developments of modals}

Once identified by means of the extra-morphological property, the microclass containing modals remained rather stable until NHG times. As already observed in $\$ 3$, it developed more and more towards strengthening its extramorphological motivation, which had the consequence of eliminating nonmodal P-Ps such as tügen, gönnen and törren, which belong now to the class of weak verbs, with the only (significant) exception of wissen. ${ }^{31}$ Moreover, the IFs have been partially reformulated as a consequence of the developments of the whole system. As an example, the 2.sg.pres.ind. suffix - $t$ (IF2 in (20) above) was slowly replaced by the super-stable marker (cf. Wurzel 1989:135ff.) -st, which occurred in all other inflectional classes. Notice that IF2 was very robust in spite of its being an isolated characteristic of this verbal class, because it survived for a long time (a form darft is still attested in the seventeenth century, cf. Ebert et al. 1993:300). Besides the restructuring of the IFs, other changes concerned the leveling of alternations produced by phonological processes. In particular, the alternation between OHG pres. kunnun and pret. kondun produced by the phonological change described above was eliminated. This leveling must be seen in the light of the development of a unitary inflection of these verbs:

Die Modalverben entwickeln sich zu einer separaten, außermorphologisch motivierten Flexionsklasse, was eine formale Vereinheitlichung mit sich bringt ... Auch das Muster müssen - müsste - musste, also identischer Vokal im umgelauteten Infinitiv, Pl.Präs. und Konj.Prät. vs. identischer, aber nichtumgelauteter Präteritalvokal, das die 'Verteilung' der teilweise phonologisch bedingten Stammvokalveränderungen regelt, z.B. $u / \ddot{u}>o / \ddot{b}$ besonders vor Nasal — können bzw. Kürzung in geschlossener Silbe — müssen, erfährt diese Vereinheitlichung. (Bittner 1996: 172)

With respect to this (apparently, but cf. Fertig 1999) unitary development, in the case of sollen the stem vowel /o/ was generalized across the whole paradigm (cf. Fertig 1999:235; 2000:70 for a discussion of the question) giving up IF3 presumably because of the influence of the following /l/, as for wollen (cf. Weinhold 1883:443). In this case, the phonological change overrode the

31. Probably, wissen stuck to its original inflectional class because of its high frequency of usage (cf. Birkmann 1987:204, 220, 374). Notice, however, that in English, where the modals form an even more peculiar inflectional class, the old P-P witan has disappeared in favor of to know (< OE cnāwan). 
pre-existing morphological relations, but favored a more general process of regularization. However, even if the role played by the cluster of IFs depicted in (20) above diminished in the course of time, IF1 (i.e., $\varnothing$-suffix in the 1/3PS.SG.PRES.IND) still remains a central feature characterizing all modal verbs (and possibly extended to verbs attracted to this microclass, cf. the brauchen case mentioned in $\$ 3$ above). IF4 has been promoted to a general feature of NHG verbal paradigms, whereas IF2 disappeared due to the diffusion of the super-stable marker -st, which was present in (or extended to) all tenses and moods. Finally, IF3 and IF5 have been reanalysed in a kind of inverted IF, stating that the preterit indicative must display a back vowel:

$$
\text { PSC: }\left[\begin{array}{c}
\mathrm{V} \\
\text { +modal }
\end{array}\right] \supset\left\{\begin{array}{l}
\text { IF1-- } \varnothing / 1 . / 3 . \text { PS.SG.PRES.IND. } \\
\text { IF2--back V/PRET.IND. }
\end{array}\right\}
$$

Thus, IF3, i.e. the stem vowel alternation condition, has lost its central status, but the microclass of modals is quite robust, and fairly well identified by means of a PSC.

\section{Conclusion}

P-Ps had a particular status within the OHG verbal system. They were characterized by different IFs with respect to the other inflectional classes. Moreover, they were mostly constituted by modal verbs, which displayed common properties of a syntactic and a semantic type. Diachronically, we observe a tendency towards anchoring the original class of P-Ps with the specific extramorphological motivation of being modals. As a consequence, the class in NHG contains almost only modals, with the significant exception of wissen. In this light, a first change found in central dialects (magun > mugun) appears motivated by the need to improve the status of the verb with respect to the IFs of the extra-morphologically motivated inflectional class. The story of umlaut seems to start with the verbs magan and muozan in Bavarian and Alemannic. In these dialects, umlaut extension was exploited to improve the inflectional status of the two verbs with respect to the IFs of the inflectional class. Umlaut extension was made possible by the action in late $\mathrm{OHG}$ of the umlaut rule in the domain of the phonological word, that ingenerated a formal neutralization between indicative and subjunctive in the plural of all modals when a clitic was postposed. In this respect, we have also highlighted the paradigmatic strength of the (for 
modals) uniform subjunctive marker $-i$-, which contributed to give rise to a functional neutralization between subjunctive and indicative. This was especially the case in the exhortative (allocutive) usage that was accompanied by inversion and cliticization of the pronoun. A peculiar characteristic of $\mathrm{OHG}$, i.e. the pervasive action of umlaut in the domain of the phonological word, accounts for the difference shown by OHG with respect to other North Germanic languages, where similar morphological changes are found.

\section{References}

Beckmann, Werner. 1990. “Zur Geschichte der deutschen Modalverben”. Niederdeutsches Wort 30.55-81.

Behaghel, Otto. 1928. Geschichte der deutschen Sprache. 5th ed. (=Grundriß der germanischen Philologie, 3.) Berlin: de Gruyter. (2nd ed., 1902.)

Birkmann, Thomas. 1987. Präteritopräsentia. Morphologische Entwicklungen einer Sonderklasse in den altgermanischen Sprachen. (= Linguistische Arbeiten, 188.) Tübingen: Niemeyer.

Bittner, Andreas. 1996. Starke, schwache' Verben - schwache, starke' Verben. Deutsche Verbflexion und Natürlichkeit. (=Studien zur deutschen Grammatik, 51.) Tübingen: Stauffenburg.

Braune, Wilhelm. 1981. Gotische Grammatik. 19th ed. by Ernst A. Ebbinghaus (=Sammlung kurzer Grammatiken germanischer Dialekte, A.1.) Tübingen: Niemeyer. (1st ed., 1880.)

Braune, Wilhelm. 1987. Althochdeutsche Grammatik. 14th ed. by Hans Eggers (=Sammlung kurzer Grammatiken germanischer Dialekte, A.5.) Tübingen: Niemeyer. (1st ed., 1886.)

Brenner, Otto. 1895. "Zum deutschen Vokalismus". Beiträge zur Geschichte der deutschen Sprache und Literatur 20.80-87.

Dal, Ingerid. 1966. Kurze deutsche Syntax auf historischer Grundlage. 3rd ed. (=Sammlung kurzer Grammatiken germanischer Dialekte, B.7.) Tübingen: Niemeyer. (1st ed., 1952.)

Carstairs, Andrew. 1986. "Macroclasses and paradigm economy in German nouns". Zeitschrift für Phonetik, Sprachwissenschaft und Kommunikationsforschung 39.3-11.

Carstairs, Andrew. 1987. Allomorphy in Inflexion. London: Croom Helm Linguistic Series.

Dressler, Wolfgang Ullrich. 1985. Morphonology. The dynamics of derivation. Ann Harbor: Karoma Press.

Dressler, Wolfgang Ullrich, Willi Mayerthaler, Oswald Panagl \& Wolfgang Ullrich Wurzel. 1987. Leitmotifs in Natural Morphology. (= Studies in Language Companion Series, 10.) Amsterdam and Philadelphia: John Benjamins.

Ebert, Robert, Oskar Reichmann, Hans-Joachim Solms \& Klaus-Peter Wegera. 1993. Frühneuhochdeutsche Grammatik ed. by Oskar Reichmann \& Klaus-Peter Wegera, (=Sammlung kurzer Grammatiken germanischer Dialekte, A.12.) Tübingen: Niemeyer.

Fertig, David. 1996. "Phonology, Orthography and the Umlaut Puzzle". Germanic Linguistics. Syntactic and Diachronic ed. by Rosina L. Lippi-Green \& Joseph C. Salmons, 169-184. (=Current Issues in Linguistic Theory, 137.) Amsterdam and Philadelphia: John Benjamins. 
Fertig, David. 1999. “Analogical 'Leveling' from Outside the Paradigm. Stem-Vowel Changes in the German Modals". Diachronica 16.233-260.

Fertig, David. 2000. Morphological Change Up Close: Two and a Half Centuries of Verbal Inflection in Nuremberg. (=Linguistische Arbeiten, 422.) Tübingen: Niemeyer.

Fiedler, H.G. 1928. "Two Problems of the German Preterit-Present Verbs". The Modern Language Review 23.188-196.

Fisiak, Jacek, ed. 1980. Historical Morphology. (=Trends in Linguistics. Studies and Monograph, 17.) The Hague: Mouton.

Gaeta, Livio. 1995. "Italian Loan Words in the Inflexional Noun System of Modern German”, Folia Linguistica 29.407-21.

Gaeta, Livio. 1998. "Some Remarks on Analogy, Reanalysis and Grammaticalization". The limits of grammaticalization ed. by Anna Giacalone Ramat \& Paul J. Hopper, 89-105. (=Typological Studies in Language, 37.) Amsterdam and Philadelphia: John Benjamins.

Gaeta, Livio. 2000. "Wege des natürlichen Sprachwandels: Die germanischen PräteritoPräsentia". Angemessene Strukturen: Systemorganisation in Phonologie, Morphologie und Syntax ed. by Andreas Bittner, Dagmar Bittner \& Klaus-Michael Köpcke, 207-222. Hildesheim: Olms.

Gaeta, Livio. 2002. "On the relation between primary and secondary umlaut". Paper delivered at the Germanic Linguistic Roundtable, Berkeley, 5-6.4.2002.

Grimme, Hubert. 1922. Plattdeutsche Mundarten. (=Sammlung Göschen, 461.) 2nd ed. Berlin: de Gruyter.

Haase, Martin. 1996. "Variation ohne Wandel. Sprachveränderungsprozesse in Mittelitalien". Sprachstrukturen und Prozesse ed. by Wolf Thümmel, vol. 1, 58-91. Osnabrück: secolo.

Hock, Hans H. 1991. Principles of Historical Linguistics. 2nd ed. Berlin \& New York: Mouton de Gruyter.

Howell, Robert B. \& Joseph C. Salmons. 1997. "Umlautless Residues in Germanic”. American Journal of Germanic Linguistics \& Literatures 9.83-111.

Iverson, Gregory K., Garry W. Davis \& Joseph C. Salmons. 1994. "Blocking environments in Old High German umlaut”. Folia Linguistica Historica 15.131-148.

Iverson, Gregory K. \& Joseph C. Salmons. 1996. “The primacy of primary umlaut”. Beiträge zur Geschichte der deutschen Sprache und Literatur 118.69-86.

Iverson, Gregory K. \& Joseph C. Salmons. 1999. "Umlaut as Regular Sound Change: The phonetic basis of 'ingenerate umlaut". Language Change and Typological Variation: In Honor of Winfred P. Lehmann on the Occasion of His 83rd Birthday, ed. by Edgar C. Polomé \& Carol F. Justus, 2 vols., 207-224, Washington: Institute for the Study of Man. Janda, Richard D. 1998. "German Umlaut: Morpholexical all the way down from OHG through NHG (Two Stützpunkte for Romance Metaphony)”. Rivista di Linguistica 10.163-232.

Kern, Peter \& Herta Zutt. 1977. Geschichte des deutschen Flexionssystems. (=Germanistische Arbeitshefte, 22.) Tübingen: Niemeyer.

Loporcaro, Michele. 1997. L'origine del raddoppiamento fonosintattico. Saggio di fonologia diacronica romanza. (=Romanica Helvetica, 115.) Basel: Francke.

Lühr, Rosemarie. 1987. “Zu Veränderungen im System der Modalverben”. Althochdeutsch. Bd. I: Grammatik, Glossen und Texte ed. by Rolf Bergmann, Heinrich Tiefenbach \& Lothar Voetz, 262-289. Heidelberg: Winter. 
Mayerthaler, Willi. 1981. Morphologische Natürlichkeit. Wiesbaden: Athenaion.

Mayerthaler, Willi. 1987. System-independent morphological naturalness. In Dressler et al. 1987, 25-58.

McLintock, David R. 1961. "Die umgelauteten Praeteritopraesentia und der Synkretismus im deutschen Verbalsystem”. Beiträge zur Geschichte der deutschen Sprache und Literatur (Tübingen) 83.271-277.

Meid, Wolfgang. 1971. Das germanische Präteritum. Innsbruck: Innsbrucker Beiträge zur Sprachwissenschaft 3.

Mettke, Heinz. 1989. Mittelhochdeutsche Grammatik. 6th ed. Leipzig: VEB Bibliographisches Institut.

Noreen, Adolf. 1923. Altisländische und Altnorwegische Grammatik (Laut- und Flexionslehre). Unter Berücksichtigung des Urnordischen. 4th ed. Halle (Saale): Niemeyer. (1st ed., 1884.)

Paul, Hermann. 1989. Mittelhochdeutsche Grammatik. 24th ed. by Peter Wiehl \& Siegfried Grosse (=Sammlung kurzer Grammatiken germanischer Dialekte, A.2.) Tübingen: Niemeyer. (1st ed., 1881.)

Pfeifer, Wolfgang. 1993. Etymologisches Wörterbuch des Deutschen. 2nd ed. Berlin: Akademie-Verlag.

Plank, Frans. 1984. “The modals story retold”. Studies in Language 8.305-364.

Ramat, Paolo. 1971. "Die Analyse eines morphosemantischen Feldes: die germanischen Modalverben”. Indogermanische Forschungen 76.174-202.

Ramat, Paolo. 1986. Introduzione alla linguistica germanica. Bologna: il Mulino.

Ronneberger-Sibold, Elke. 1990a. "Zum Auf- und Abbau des Rückumlauts bei den schwachen Verben”. Wurzel(n) der Natürlichkeit. Studien zur Morphologie und Phonologie IV ed. by Armin Bassarak, Dagmar Bittner, Andreas Bittner \& Petra Thiele, 119-132. (=Linguistische Studien. Reihe A, 208.) Berlin: Zentralinstitut für Sprachwissenschaft.

Ronneberger-Sibold, Elke. 1990b. "Zur Verselbstständigung sprachlicher Einheiten: Der deutsche Umlaut". Spielarten der Natürlichkeit — Spielarten der Ökonomie. Beiträge zum 5. Essener Kolloquium ed. by Norbert Boretzky \& Thomas Stolz, vol. 2, 185-205. Bochum: Brockmeyer.

Schirmunski, Victor M. 1962. Deutsche Mundartkunde. Berlin: Akademie-Verlag.

Ščur, Georgij S. 1961. "Über den Umlaut der deutschen Modalverben”. Neuphilologische Mitteilungen 62.206-219.

Seebold, Elmar. 1970. Vergleichendes und etymologisches Wörterbuch der germanischen starken Verben. The Hague: Mouton.

Tiersma, Peter. 1978. "Bidirectional levelling as evidence for relational rules". Lingua 45.65-77.

Tiersma, Peter. 1982. "Local and general markedness". Language 58.832-849.

Vennemann, Theo. 1972. "Rule inversion”. Lingua 29.209-242.

Vennemann, Theo. 1974. "Restructuring”. Lingua 33.137-156.

Vennemann, Theo. 1986. "Ruckümläut". Linguistic across Historical and Geographical Boundaries. In honour of Jacek Fisiak on the occasion of his 50th birthday ed. by Dieter Kastovsky \& Aleksander Szwedek, vol. 1, 701-723. Berlin \& New York: Mouton de Gruyter. Vincent, Nigel. 1980. "Word vs. morphemes in morphological change: the case of Italian -iamo”. In Fisiak 1980, 383-398. 
Voyles, Joseph. B. 1991. “A History of OHG i-umlaut”. Beiträge zur Geschichte der deutschen Sprache und Literatur 113.159-194.

Weinhold, Karl. 1883. Mittelhochdeutsche Grammatik. 2nd ed. Paderborn: Schöningh.

Wurzel, Wolfgang U. 1980. "Ways of morphologizing phonological rules". In Fisiak 1980, 443-462.

Wurzel, Wolfgang U. 1984. "Was bezeichnet der Umlaut im Deutschen?". Zeitschrift für Phonetik, Sprachwissenschaft und Kommunikationsforschung 37.647-663.

Wurzel, Wolfgang U. 1987a. "System-dependent morphological naturalness in inflection". In Dressler et al. 1987, 59-96.

Wurzel, Wolfgang U. 1987b. "Paradigmenstrukturbedingungen: Aufbau und Veränderung von Flexionsparadigmen". Papers from the 7th International Conference on Historical Linguistics ed. by Anna Giacalone Ramat, 629-644. Amsterdam \& Philadelphia: John Benjamins.

Wurzel, Wolfgang U. 1989. Inflectional morphology and naturalness. Dordrecht: Kluwer. [German original: Flexionsmorphologie und Natürlichkeit, Berlin: Akademie-Verlag, 1984.]

Wurzel, Wolfgang U. 1994a. "Skizze der natürlichen Morphologie". Papiere zur Linguistik 50.23-47.

Wurzel, Wolfgang U. 1994b. Grammatisch initiierter Wandel. Bochum: Brockmeyer.

\section{Summary}

The umlauted forms of the German modals dürfen, mögen, müssen and können are unexpected from the viewpoint of the sound laws, and must be therefore explained in other ways. Despite more than one century of research, a convincing solution to this problem is still lacking. In this paper, a new solution is proposed, which attempts to consider the several factors implied by this linguistic change. As observed by Lühr (1987), mögen and müssen seem to have been the first verbs to show umlaut extension, especially in Southern dialects. This fact can be explained as a morphologically driven language change, since the two verbs were inadequate with respect to the paradigm-structure conditions of the modals' inflectional class. The extension of umlaut established a stem vowel alternation between the singular and the plural of the present indicative as in all other verbs of the inflectional class. Therefore, umlaut extension can be seen as the result of a morphological change increasing the system adequacy of the verbs (cf. Wurzel 1989). Two other factors were crucial for the linguistic change. The functional neutralization of the mood opposition between the indicative and the subjunctive, typical of this verbal class, might also have played a role, because the subjunctive displayed an umlaut-triggering suffix. Moreover, umlaut extension may also be seen as the result of an additional process of phonological neutralization caused by the action of the umlaut rule in the context of a phonological word in late OHG, as already pointed out by Behaghel (1928). 


\section{Résumé}

Les formes avec umlaut dans les verbes modaux allemands dürfen, mögen, müssen et können n'ont pas une origine phonétique. Après plus d'un siècle de recherche on n'a pas encore trouvé d'explication convaincante pour ce phénomène. Dans cet article, on propose une nouvelle solution au problème, qui tente de prendre en considération les nombreux facteurs liés à ce changement linguistique. Comme l'a observé Lühr (1987), mögen et müssen ont été les premiers verbes à montrer l'extension de l'umlaut, particulièrement dans les dialectes méridionaux. Ce fait peut s'expliquer par l'état morphologiquement inadéquat de ces deux verbes quant aux conditions de la structure paradigmatique de cette classe flexionnelle. En effet, l'umlaut a établi une alternation de la voyelle radicale entre le singulier et le pluriel du présent de l'indicatif, comme dans tous les autres verbes de cette classe flexionnelle. Dans cette optique, l'extension de l'umlaut serait un changement morphologique qui a amélioré la régularité du système verbal (cf. Wurzel 1989). Deux autres facteurs auraient joué un rôle décisif dans ce changement langagier. La neutralisation fonctionnelle de l'opposition de mode entre l'indicatif et le subjonctif, typique de cette classe verbale, peut aussi avoir joué un rôle dans ce changement, en raison de la présence dans ces verbes d'un suffixe qui produisait l'umlaut au subjonctif. Enfin, le phénomène d'extension de l'umlaut peut aussi s'expliquer comme étant le résultat de l'action neutralisante de la règle phonologique de l'umlaut, qui agissait en vieil-allemand dans le contexte du mot phonologique, comme l'avait déjà observé Behaghel (1928).

\section{Zusammenfassung}

Die umgelauteten Formen der deutschen Modalverben dürfen, mögen, müssen und können sind lautgesetzlich unerwartet. Nach mehr als einem Jahrhundert Forschung, bleibt eine überzeugende Lösung noch offen. In diesem Aufsatz wird eine neue Lösung vorgeschlagen, in der die in diesem Sprachwandel miteinbezogenen verschiedenen Elemente genauer betrachtet werden. Wie von Lühr (1987) schon bemerkt wurde, sind mögen und müssen die ersten Verben gewesen, die die Umlautausdehnung, besonders in oberdeutschen Mundarten, gezeigt haben. Diese Feststellung kann dadurch erklärt werden, dass diese zwei Verben in Bezug auf die Paradigmenstrukturbedingungen ihrer Flexionsklasse unangemessen waren. Von diesem Blickpunkt hat der Umlaut eine Alternanz des Stammvokals zwischen Singular und Plural des Präsens Indikativs geschaffen, die in den anderen Verben der Flexionsklasse üblich war. In dieser Perspektive ist die Umlautausdehnung das Ergebnis eines morphlogischen Wandels gewesen, der die Systemangemessenheit der Verben verbessert hat (vgl. Wurzel 1989). Darüber hinaus müssen zwei andere Aspekte hervorgehoben werden. Die für die Modalverben typische Markiertheitsumkehrung zwischen Indikativ und Konjunktiv, wo es ein umlautauslöschendes Suffix gab, kann auch dazu beigetragen haben, die Umlautausdehnung zu begünstigen, weil eine funktionale Neutralisierung der Modusopposition in dieser Verbklasse zustande kam. Schließlich kann die Umlautausdehnung auch als das Ergebnis der neutralisierenden Auswirkung der phonologischen Umlautregel gesehen 
werden, die im Ahd. das phonologische Wort als Domäne hatte, wie es von Behaghel (1928) schon vorgeschlagen wurde.

\section{Author's address}

Livio Gaeta

Dipartimento di Scienze del Linguaggio

e Letterature moderne e comparate

Università di Torino

via S. Ottavio 20, I-10124

TORINO

Italy

e-mail: livio.gaeta@unito.it 